\title{
FUNGSI TARI PERSEMBAHAN TEPAK SIRIH DALAM MEMERIAHKAN ACARA HBD INDONESIA DIBKB PALEMBANG
}

\author{
Oleh: \\ Treny Hera \\ (Dosen FKIP Prodi Pendidikan Sendratasik Universitas PGRI Palembang) \\ ABSTRAK
}

Apresiasi penonton dinilai berpengaruh terhadap pertunjukan tari ketika suatu tarian berfungsi sebagai tontonan dan hiburan yang memberikan pengalaman estetis bagi yang menyaksikan pertunjukannya. Pengalaman estetis tersebut dapat dicapai dan dirasakan oleh penonton sebagai apresiator melalui indera visualnya saat penonton menyaksikan pertunjukan tari dari awal hingga akhir pertunjukan. Di Kota Palembang Provinsi Sumatera Selatan tari berfungsi sebagai hiburan dan tontonan dalam sebuah konteks pertunjukan. Elemen pertunjukan tari perlu diapresiasi diantaranya gerak tari, musik tari, pola lantai, dan tata busana sehingga elemen pertunjukan sebuah tarian akan memiliki fungsi dalam memperoleh apresiasi penonton yang nantinya akan menentukan kualitas sebuah pertunjukan. Beragamnya elemen tari yang dipertunjukkan akan menunjukkan nilai estetis sebuah pertunjukan tari dan memberi suatu pengalaman seni bagi penonton sebagai penikmat yang terhibur melalui tontonan yang dipertunjukkan.

Kata Kunci : Fungsi, Pertunjukan, Tari

\section{A.PENDAHULUAN}

Masyarakat Kota Palembang Provinsi Sumatera Selatan memiliki perhatian yang cukup besar terhadap perkembangan seni tari tradisonal khususnya. Hal ini dikarenakan kecintaan masyarakat setempat kepada seni tari tradisonal sebagai aset budaya yang perlu dijaga nilai dan keberadaannya. Menjaga seni tari sebagai salah satu perwujudan budaya melalui apresiasi pertunjukan tari sebagai bentuk menghargai adanya keberadaan tari tersebut. Karena sudah tak jarang khususnya generasi muda untuk mencintai seni tari tradisonal yang dianggap kurang modern. Karena di zaman era globalisasi ini telah banyak bermunculan tari kreasi baru yang lebih menarik perhatian para generasi muda untuk bergerak dan berpenampilan modern dari segi busana saat mempertunjukkan sebuah tari. Mengapa perhatian difokuskan pada generasi muda, karena merekalah nantinya yang akan meneruskan, melestarikan, dan menjaga keberadaan seni tradisional kita ini.

Tari merupakan bentuk seni yang sangat erat hubungannya dengan segi-segi kehidupan manusia, seperti bentuk sosial, budaya, ekonomi, yang banyak melibatkan pertunjukan seni tari yang berfungsi sebagai hiburan dan tontonan, yang bertujuan untuk melibatkan suatu budaya yang dimiliki menjadi bagian dari acara yang ada, baik acara seremonial maupuan acara adat pernikahan yang membudaya di Kota Palembang, salah satunya bentuk nyata suatu 
acara akan dimulai dengan diawali oleh pertunjukan tari sebagai pembuka acara. Salah satunya adalah acara Hari Belanja Diskon Indonesia (HBD) indonesia yang merupakan program Badan Standarisasi Nasional dengan menggelar pemecahan rekor MURI baru untuk pempek terbanyak, yaitu 18818 buah dalam pembukaan Hari Belanja Diskon Indonesia yang dibagikan secara gratis kepada masyarakat. Acara tersebut merupakan salah satu rangkaian dalam menyambuat Asean Games di Palembang tahun 2018. Menarik perhatian penonton di Benteng Kuto Besak (BKB) pada saat dipertunjukkan tari Persembahan Tepak Sirih yang diutamakan untuk menyambut Menteri Pariwisata Arief Yahya dan PJ Walikota Palembang, Akhmad Najib sebagai tamu agung dan tamu kehormatan yang bertandang ke Kota Palembang. Puncak acara terasa meriah dan hikmat ketika tari massal Persembahan Tepak Sirih dipertunjukkan oleh 73 penari sesuai dengan HUT Indonesia.

\section{B. METODE PENELITIAN}

Penelitian ini menggunakan metode penelitian kajian budaya secara deskriptif kualitatif, yaitu metode penelitian dengan cara menyajikan data secara deskripsi kata-kata.

Metode penelitian adalah cara yang mengatur prosedur penelitian pada umunya, sekaligus pelaksanaannya terhadap masing- masing ilmu secara khusus. Metode kualitatif ini memanfaatkan cara-cara penafsiran dengan menyajikannya dalam bentuk deskripsi (Nyoman, 2010:306).

Cara pengumpulan data dalam penelitian fungsi tari Persembahan Tepak Sirih dalam memeriahkan acara HBD Indonesia di BKB Kota Palembang melalui pengumpulan data yg dilakukan dari proses/tahapan pertunjukan. "Pengumpulan data dilakukan melalui tahap alamiah, menggunakan sumber primer, dan sumber sekunder. Sumber primer adalah sumber data yang langsung memberikan data kepada pengumpul data dan sumber sekunder merupakan sumber yang tidak langsung memberikan data" (Nyoman, 2010:141).

\section{PEMBAHASAN DAN HASIL PENELITIAN}

Soedarsono (2002:216) menjelaskan "Seni pertunjukan adalah seni kolektif, hingga penampilannya di atas panggung menuntut biaya yang tidak sedikit. Untuk menampilkan sebuah pertunjukan tari misalnya, diperlukan penari, busana tari, penata rias, pemain musik apabila iringannya musik hidup, panggung pertunjukan." Berdasarkan enam elemen pertunjukan yang diperlukan dalam sebuah pertunjukan seni tari maka penggunaan teori di atas untuk membahas fungsi tari Persembahan Tepak Sirih dalam memeriahkan acara HBD Indonesia dengan mempertunjukkan 73 penari, dapat digunakan. 
Soedarsono (2002:123) menjelaskan "Seni pertunjukan disebut sebagai seni pertunjukan karena dipertunjukkan bagi penikmat. Secara garis besar seni pertunjukan memiliki tiga fungsi primer, yaitu (1) sebagai sarana ritual; (2) sebagai ungkapan pribadi yang pada umumnya berupa hiburan pribadi; (3) sebagai presentasi estetis."

Kesenian sebagai salah satu unsur kebudayaan memiliki hubungan yang erat dan tidak bisa lepas dari lingkungan masyarakat pendukung dimana kesenian itu lahir. Ia tidak mandiri, tapi luluh erat dengan adat setempat, pandangan hidup, tata masyarakat dan agama atau kepercayaan yang secara turun temurun telah diakui keberadaannya oleh masyarakat di lingkungan kesenian itu lahir, (Suharto, 1999:38). Tari Persembahan Tepak Sirih merupakan keberagaman tari sambut di Kota Palembang yang lahir berdasarkan pandangan hidup dan tata masyarakat setempat sebagai pemakai barang seni tersebut.

Fungsi seni pertunjukan tari merupakan aktivitas kesenian dalam suatu konteks sosial, budaya, pariwisata dan ekonomi dalam suatu acara yang membutuhkan, didukung oleh masyarakat sebagai penonton sehingga kesenian tersebut benar berperan sebagai sebuah tontonan dan hiburan.

Seni tari merupakan salah satu cabang kesenian atau seni yang pengungkapannya dengan seni media ekspresi anggota badan manusia di dalam ruangan yang didukung oleh musik iringan, tata rias dan kostum, properti dan perlengkapan lainnya sehingga dapat menarik perhatian penikmat seni serta memberi gambaran yang jelas.

Tari merupakan salah satu bentuk acara yang menjadi legitimasi khusunya di Palembang Sumatera Selatan sebagai tanda membuka acara yang ditandai dengan pertunjukan tari dengan persembahan tepak sirih yang merupakan wujud mengungkapkan saling menghormati sesama manusia, dalam konteks menyambut tamu. Pertunjukan diawal diadakan dalam lingkungan kehidupan masyarakat pemiliknya, untuk mendapatkan apresiasi dan menyampaikan pesan dari sebuah rangkaian tari yang dipertunjukan.

Dalam hal ini tari Persembahan Tepak Sirih memiliki pesan yang disampaikan kepada penonton bahwa keramah tamahan dan rasa saling menghormati ditandai dengan persembahan sekapur sirih yang menjadi budaya Sumsel salah satu wujud budaya Melayu.

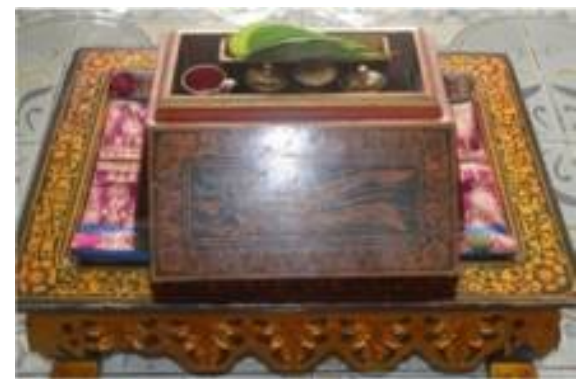

Tepak Sekapur Sirih yang disuguhkan kepada tamu sebagai pengantar kata 
Berdasarkan hasil analisis pertunjukan tari Persembahan Tepak Sirih dalam memeriahkan acara HBD Indonesia pada tanggal 8 Agustus 2018, fungsi tari Persembahan Tepak Sirih sebagai sarana upacara pembukaan acara HBD Indonesia ditandai dengan persembahan tepak sirih untuk Menteri Pariwisata RI, Arief Yahya dan PJ Walikota Palembang, Akhmad Najib sebagai tamu kehormatan pada acara tersebut.

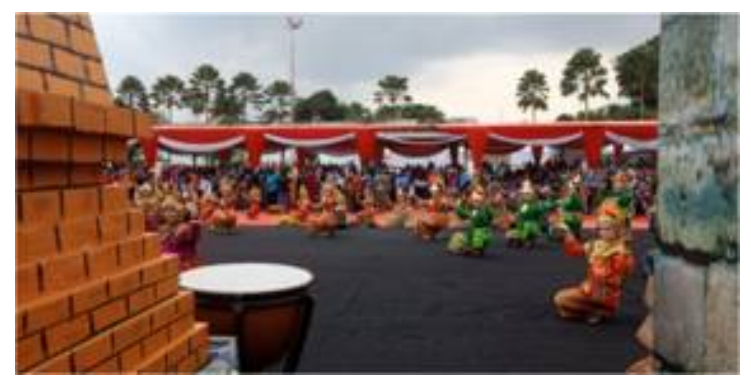

Foto diambil saat penari menyuguhkan tepak sirih kepada Menteri Pariwisata RI, Arief Yahya dan PJ Walikota Palembang, Akhmad Najib sebagai tamu kehormatan, tampak di foto penonton memenuhi tempat pertunjukan untuk menyaksikan kemeriahan acara tersebut, artinya pertunjukan tari Persembahan Tepak Sirih yang ditarikan secara massal berfungsi sebagai tontonan.

Semula acara dimeriahkan oleh pembagian pempek secara gratis dengan jumlah 18.818 buah kepada masyarakat yang datang ke BKB sebagai acara menyambut Asean Games dengan puncak acaranya terletak pada pertunjukan tari Persembahan Tepak Sirih yang berlangsung pada pukul 15.30 WIB di halaman BKB di depan ribuan penonton yang menyaksikan dari depan panggung dan sisi kanan kiri panggung dipadati oleh penoton.

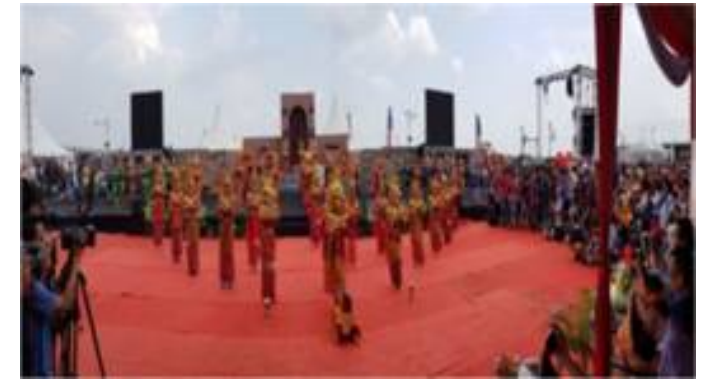

Penari berjumlah 73 orang mempertunjukan tari Persembahan Tepak Sirih Pada Acara HBD Indonesia dikelilingi oleh ribuan penonton.

Seni dipertunjukkan untuk ditonton oleh masyarakat. Fungsi tari sebagai tontonan dapat diamati pada pertunjukan tari untuk kemasan pariwisata, untuk penyambutan tamu-tamu penting atau tamu pejabat, untuk festival pertunjukan tari yang digunakan pada acaraacara tersebut biasanya sudah dikemas dan dipersiapkan menjadi sebuah tari dengan bentuk yang telah melewati suatu proses penataan, baik gerak tarinya maupun musik iringannya sesuai dengan kaidah-kaidah artistik.

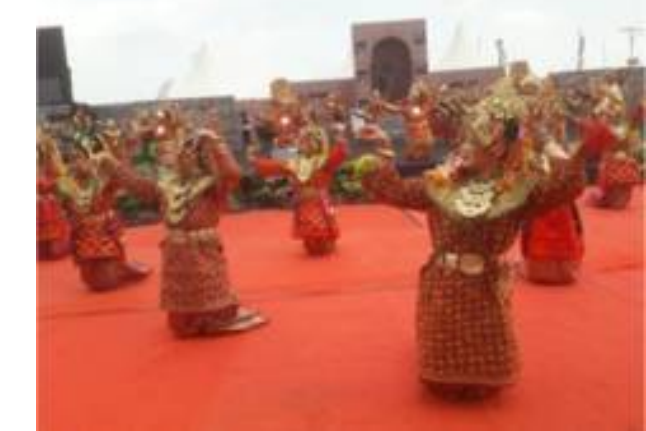

Elemen pertunjukan Tari pada acara tersebut telah dikemas dan dipersiapkan yang melewati suatu proses penataan, baik gerak tarinya, busananya maupun musik iringannya sesuai dengan kaidah-kaidah artistik berdasarkan kesepakatan bersama. 
Apresiasi penoton yang sangat luar biasa terhadap pertunjukan tari Persembahan Tepak Sirih, ditarikan oleh 73 penari mahasiswa FKIP Universitas PGRI Palembang dengan gerakan tari tradisional Kota Palembang, didukung oleh busana tari sambut khas Kota Palembang. Data tersebut diperoleh dari pengamatan terhadap keberadaan penonton yang tetap berdiri di tengah-tengah acara dan tidak meninggalkan tempat pertunjukan, dari awal tari dibuka hingga tari berakhir.

Walaupun kala itu waktu pertunjukan masih dengan cuaca panas, pelaksanaan menari massal dimulai pada pukul 15.30 WIB namun kondisi waktu tersebut tidak menutup perhatian penonton untuk tetap menyaksikan pertunjukan tari Persembahan Sekapur Sirih hingga berakhirnya pementasan. Hasil observasi di atas menunjukan bahwa penonton tidak merasa bosan menyaksikan pertunjukan tari dengan durasi waktu tujuh menit lamanya, maka dapat dikatakan memang acara tersebut dapat meriah dengan adanya pertunjukan tari Persembahan Sekapur Sirih. Data yang diperoleh melalui observasi relevan dengan landasan teori suharto yang menyebutkan bahwa "Kesenian sebagai salah satu unsur kebudayaan memiliki hubungan yang erat dan tidak bisa lepas dari lingkungan masyarakat pendukung dimana kesenian itu lahir. Ia tidak mandiri, tapi luluh erat dengan adat setempat, pandangan hidup, tata masyarakat dan agama atau kepercayaan yang secara turun temurun telah diakui keberadaannya oleh masyarakat di lingkungan kesenian itu lahir." Artinya para penari dari Universitas PGRI Palembang dengan tata rias panggung dilengkapi dengan pakaian adat palembang mampu memeriahkan acara tersebut didukung oleh tata masyarakat Kota Palembang yang membutuhkan tarian sebagai tontonan dan hiburan dalam kebudayaannya.

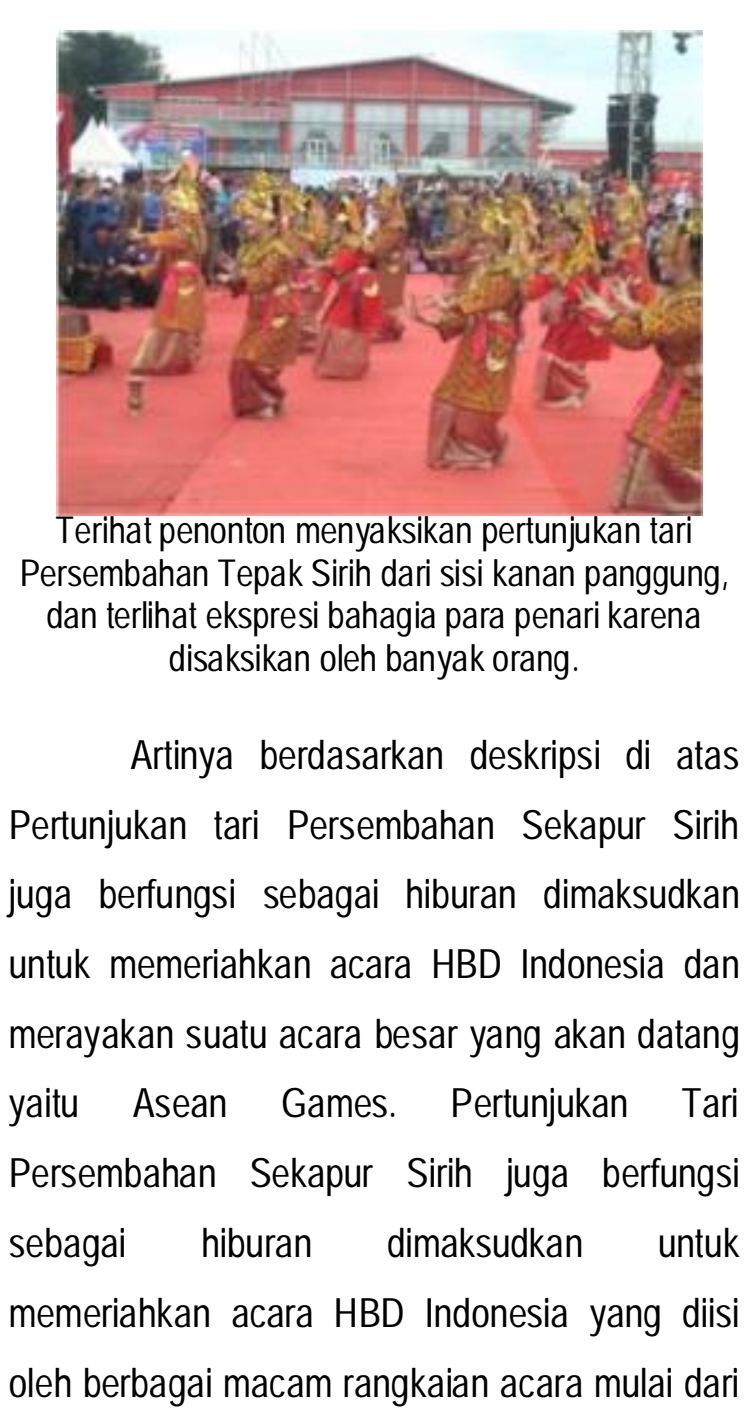


pagi hari hingga malam hari. Pagi hari kegiatan tersebut diisi dengan tari kreasi, siang harinya dimeriahkan oleh Tari Persembahan Sekapur Sirih, hingga malam hari diisi dengan tari Gending Sriwijaya.

Dalam rangka Hari Belanja Diskon Indonesia, dan sekaligus merayakan HUT ke-73 RI, Badan Standarisasi Nasional menggelar pemecahan rekor MURI baru untuk pempek terbanyak 18818 yang diselenggarakan pada hari Rabu 8 Agustus 2018 di pelataran Benteng Kuto Besak (BKB). Tujuan daripada kegiatan HBD Indonesia denga mempertunjukkan 73 penari Tari Persembahan Sekapur Sirih adalah sesuai dengan HUT Indonesia yang ke 73.

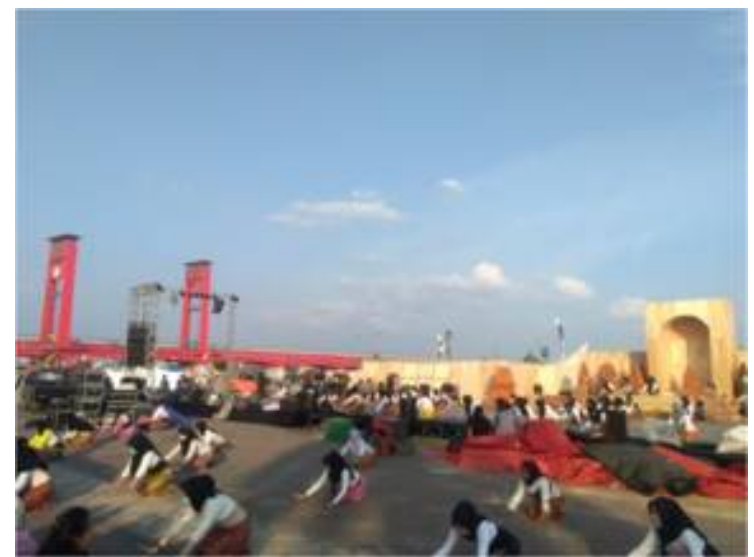

73 penari saat melakukan persiapan pada tanggal 7 agustus 2018 menjelang suksesnya kemeriahan acara Hari Belanja Diskon Indonesia (HBDI), dan sekaligus merayakan HUT ke-73 RI di BKB.

Susunan pola lantai 73 penari di atas panggung sangat memukau apresiasi penonton karena tak jarang tari sambut di Kota Palembang ditarikan secara massal. Kegiatan HBD Indonesia ini dapat sukses tentunya karena dukungan oleh pengisi acara dan keberadaan penonton sebagai penikmat yang mendapatkan hiburan melalui kegiatan tersebut.

Sebanyak 73 penari Program Studi Pendidikan Sendratasik Fakultas Keguruan dan IImu Pendidikan (FKIP) Universitas PGRI Palembang turut memeriahkan Hari Belanja Diskon Indonesia, yang dilaksanakan oleh Badan Standardisasi Nasional dengan menampilkan tari Sekapur Sirih massal, di pelataran BKB untuk menyambut Menteri Pariwisata, Arief Yahya, PJS Walikota Palembang, Akhmad Najib, dan pejabat lainnya. (Sumber: Sumateranews.co.id)

Berikut hasil apresiasi dari surat kabar:

Ke 73 mahasiswa tersebut didampingi oleh dosen pembimbing, Rully Rochayati M.Sn, Treny Hera M.Sn, dan Misral M.Sn. Tarian Sekapur Sirih massal ini merupakan rangkaian tampilan budaya dalam menyambut hari kemerdekaan Republik Indonesia dan Asian Games 18 Agustus 2018. 73 mahasiswa yang tampil tersebut merupakan representasi dari hari ulang tahun ke-73 Republik Indonesia. Selain itu, terdapat rangkaian acara lainnya yaitu parade kapal hias, pemecahan rekor Muri baru pempek terbanyak berjumlah 18818 yang merupakan representasi dari tanggal pembukaan Asian Games yang akan dilaksanakan pada tanggal 18-8-18, dan malamnya dilanjutkan festival Sriwijaya. Rektor UPGRI, $\mathrm{Dr} \mathrm{H}$ Bukman Lian MM MSi, menyambut baik kegiatan ini. " Kami mengucapkan terima kasih kepada Dinas Pariwisata 
yang telah mempercayakan kepada mahasiswa kami untuk mempersembahkan tari Sekapur Sirih massal di pelataran BKB. Dengan demikian Dinas Pariwisata memberikan kesempatan kepada mahasiswa kami untuk menunjukkan hasil berlatih dan belajar di program studi sendratasik FKIP universitas PGRI Palembang kepada masyarakat", tuturnya. Sementara Dekan FKIP, Dr Dessy Wardiah M.Pd. sepenuhnya mendukung sekaligus bangga kepada mahasiswa program studi sendratasik FKIP Universitas PGRI Palembang. " Saya mengucapkan terima kasih kepada Dinas Pariwisata yang telah memberikan kepercayaan kepada mahasiswa kami untuk tampil dalam kegiatan tersebut. Saya bangga kepada mahasiswa program studi sendratasik yang telah mampu menunjukkan eksistensinya di tengah masyarakat", pungkasnya. (Sumber: FKIP UPGRI/Ht Editor: Syarif)

Pertunjukan tari Persembahan Sekapur Sirih dengan jumlah 73 penari melalui proses persiapan, latihan, gladi, hingga pementasan. Proses persiapan dilakukan mulai dengan tahap mengumpulkan 73 mahasiswa FKIP Universitas PGRI untuk bersedia menari secara massal dalam acara HBD Indonesia sampai tahap latihan menari di halaman gedung $E$ Universitas PGRI Palembang pada sore hari secara drill dan pembentukan pola lantai serta susunan penari masuk sampai keluar panggung. Tahapan ini dilakukan atas kerja sama tim yang baik dan bersemangat untuk menampilkan pertunjukan tari yang baik sesuai harapan karena membawa nama lembaga sehingga butuh profesionalitas dari penari dan pelatih.

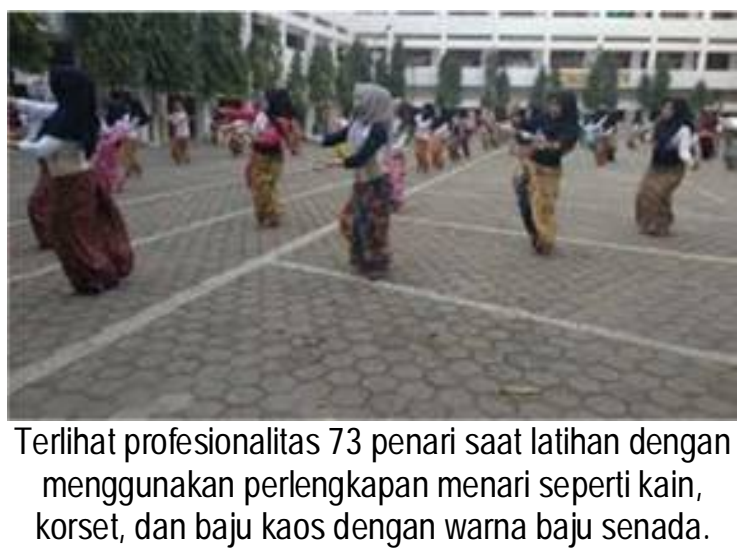

Kerja keras yang dilakukan 73 penari, pelatih, ketua jurusan pendidikan kesenian, serta team produksi FKIP dalam mempersiapkan penampilan pada acara tersebut dipersiapkan dengan profesional untuk memberikan hasil yang baik pada lembaga.

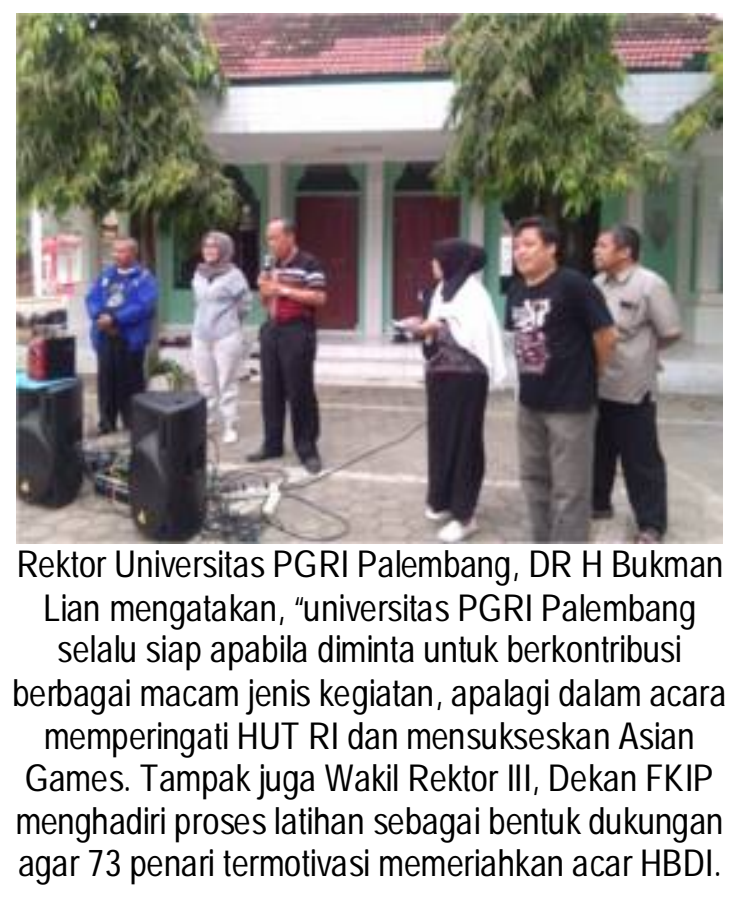


"Kita akan menampilkan 73 penari sesuai dengan HUT RI ke-73, semuanya dari mahasiswa prodi Sendratasik," ungkapnya, Minggu (5/8/2018). Dari 73 penari ini akan menampilkan pentas seni berupa Tari Tanggai hingga tarian Tepak. "Kita diminta dari Dinas Pariwisata Kota Palembang, karena pernah melihat penampilan kita pada pentas seni tari massal se Dunia. Persiapanpun hanya beberapa hari, mengingat mereka memang sudah terkoordinasi dan memang menjadi kegiatan kampus," tambah Wakil Rektor (Warek) PGRI Palembang. (http:///palembang.tribunnews.com/2018/08/05/73penari-universitas-pgri-meriahkan-hari-belanjadiskon-indonesia-di-bkb)

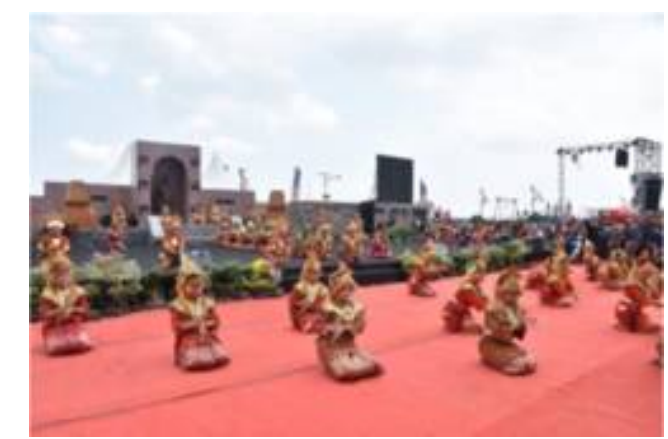

Penari mempertunjukan tari tersebut sebagai pengalaman estetis yaitu perasaan yang terhibur.

Secara khusus sebagai pengisi acara tersebut memperoleh tanggapan apresiasi yang luar biasa dari panitia penyelenggara acara dan yang lebih penting adalah penonton sebagai apresiator. Pertunjukan tersebuat mampu memeriahkan acara HBD Indonesia sebagai suatu hasil aktivitas seni yang dapat memberi kepuasan pada mata apresiator dan hati penikmatnya.

\section{SIMPULAN}

Apresiasi masyarakat Kota Palembang yang menyaksikan pertunjukan tari Persembahan Tepak Sirih yang ditarikan massal oleh 73 penari memiliki daya apresiasi yang cukup besar, hal ini diperoleh dari pengamatan terhadap penonton yang membanjiri halaman BKB saat pertunjukan tari Persembahan Tepak Sirih sampai dengan berakhirnya tarian tersebut.

Masyarakat dapat menonton dari depan panggung dan sisi kiri kanan panggung yang akhirnya mencapai pengalaman estetis penonton sebagai penikmat melalui pandangan mata sampai dengan hati maupun perasaan yang penonton dapatkan setelah menyaksikan pertunjukan tari tersebut. Artinya tujuan daripada pementasan tari Persembahan Tepak Sirih sesuai dengan fungsi seni itu sendiri yaitu sebagi tontonan dan hiburan.

Dikatakan tontonan dalam konteks ini adalah tak jarang mempertunjukkan tari sambut dengan jumlah penari 73 orang dengan formasi pola lantai yang bervariasi sehingga menarik perhatian penonton. Suatu aktivitas seni bisa dikatan memberikan hiburan ketika mata dan hati penonton tertuju pada keseluruhan objek pertunjukan tari dan memberikan respon salah satunya adalah ekspresi gembira disertai tepukan tangan dan meriah saat pertunjukan tari berakhir. Hal ini disimpulkan bahwa menganggap 
tari sebagai aktivitas seni untuk masyarakat penarinya, tamu kehormatan, dan penonton adalah kesenangan atau hiburan bersama, baik sebagai apresiator.

untuk pelaku pertunjukan bidang musik,

\section{DAFTAR PUSTAKA}

http://palembang.tribunnews.com/2018/08/05/73-penari-universitas-pgri-meriahkan-hari-belanja-diskonindonesia-di-bkb

http://sumateranews.co.id/?p=2323

Ratna, Nyoman Kutha. 2010. Metode Penelitian Kajian IImu Budaya Dan IImu Sosial Humaniora Pada Umumnya. Yogyakarta: Pustaka Belajar.

Soedarsono. 2002. Seni Pertunjukan Indonesia. Jogjakarta: Gadjah Mada University Press.

Suharto, Ben. 1999. Tayub: Pertunjukan dan Ritus Kesuburan. Bandung: Masyarakat Seni Pertunjukan Indonesia (MSPI). 